\title{
Improving Yield and Quality of Sugar Beet Using Boron at Different Levels of Nitrogen Fertilizer
}

\author{
Ferweez, H.; M.F.M.Ibrahim and A.M. Allan ${ }^{1}$
}

\begin{abstract}
Low quality of sugar beet roots is one of the problems which face expanding in agriculture of sugar beet in Middle Egypt; especially El-Minia Governorate .This trial was conducted at Mallawi Agric.Res. Station ,El-Minia, Egypt, during 2008/2009 and 2009/2010 seasons to determine the optimal level of boron and nitrogen fertilizer to obtain the highest yield and quality of sugar beet . Split plot design with four replications was used. Nitrogen fertilizer levels i.e. 80,100 and $120 \mathrm{~kg} / \mathrm{fed}$ were arranged in the main plots. Boron, as boric acid, was foliar sprayed at $0.00,0.05$ and $0.10 \%$ and allocated in the sub plots. Foliar applications of boron were applied at 80 days after planting.
\end{abstract}

The obtained results revealed that boron and nitrogen fertilizer levels had a significant effect on vegetative traits, i.e. root length and diameter $(\mathrm{cm})$, quality charateristics (pol\%, $\mathrm{Na}, \mathrm{K}, \alpha-\mathrm{N}$ contents, sugar recovery $\%$ and quality index) and productivity parameters of sugar beet (root and sugar yields ton/fed) in the two growing seasons and the combined.

Applying fertilization of sugar beet by $100 \mathrm{~kg} \mathrm{~N} /$ fed with foliar application of boron with $0.10 \%$ ( as boric acid) is recommended under Middle Egypt conditions (El-Minia Governorate conditions) because it gave the hightest value of recoverable sugar yield (4.39 ton/ fed) of sugar beet compared with the other.

Keywords: sugar beet,boron, sugar recovery\%, pol\% and quality index.

\section{INTRODUCTION}

Because of the limited irrigation water and the fertile land it is not possible to expand horizontally for sugar cane crop. The Egyptian Government's strategy to fulfill sugar needs depend on increasing sugar production from sugar beet. Recently, sugar beet crop (Beta vulgaris L.) occupied an important position in Egyptian crop rotation as winter crop. The sugar produced from sugar beet increased from $7.36 \%$ in 1990 to about $49.70 \%$ in 2010 season of the total local sugar production (1.99 million ton) (CCSC, 2011 ).

Sugar beet quality involves two concepts, the percent of sucrose and the level of impurities in the root, both of which affect the extraction of sucrose. Low quality of sugar beet roots is one of the problems which face expanding the growing of sugar beet in Middle Egypt, especially El-Minia Governorate. Most of the
Egyptian soils suffer from micronutrients deficiency such as boron element as a result of the intensive cropping. Hassanin \& Abu El.Dahab, (1991) and Narayan et al. (1991) reported that spraying sugar beet plants with $0.05 \%$ boron led to a markedly increase in root and sugar yields (ton/fed) compared with the control.

With respect to nitrogen fertilizer, Sarhan (1998); El.Hawary (1999) and Attia et al. (2004) found that nitrogen fertilizer improved growth and yield components of sugar beet, where, increasing nitrogen fertilizer level up to $100 \mathrm{~kg} / \mathrm{fed}$ enhanced growth attributes of sugar beet. They revealed that the increment of growth attributes gained by increasing nitrogen fertilizer level may be due to the role of nitrogen in developing root dimensions by increasing division or elongation of cells and also enhancing leaf initiation and increment chlorophyll concentration in leaves and photosynthesis process.This was associated with the accumulation of carbohydrates transferred from leaves to developing roots, consequently increasing root size.

The objective of this work was to determine the optimal level of boron and nitrogen needed to obtain the highest yield and quality of sugar beet under Middle Egypt, especially El-Minia Governorate conditions.

\section{MATERIALS AND METHODS}

The present work was conducted at Mallawi Agric.Res.Station El .Minia Governorate, Egypt, during 2008/2009 and 2009/2010 seasons in split plot design with four replications. Sugar beet variety namely Montebianco was used and sown on $15^{\text {th }}$ and $18^{\text {th }}$ October in the two seasons, respectively. Nitrogen fertilizer levels i.e. 80, 100 and $120 \mathrm{~kg} / \mathrm{fed}$ were arranged in the main plots. Boron as boric acid was foliar sprayed at $0.00,0.05$ and $0.10 \%$ allocated in the sub plots.

Sub plots area were $10.5 \mathrm{~m}^{2}$ (each consisting of five rows60 cm wide and 3.5 meters long, in hills $17 \mathrm{~cm}$ apart. Nitrogen fertilizer in form of Urea (46.5\%) was added in two equal doses (the first one after 25 days from sowing and the second one 30 days later) as well as phosphorus fertilizer was added at recommended rate of $30 \mathrm{kgs} \mathrm{P}_{2} \mathrm{O}_{5} /$ fed. at planting. Potassium fertilizer in form of potassium sulphate $\left(48 \% \mathrm{~K}_{2} \mathrm{O}\right)$ was added with the second dose of nitrogen fertilizer at recommended

\footnotetext{
${ }^{1}$ Sugar Crops Res. Inst., Agric. Res. Centre, Giza, Egypt.

Received March 14, 2011, Accepted March 27, 2011
} 
rate of $24 \mathrm{~kg} \mathrm{~K}_{2} \mathrm{O}$ / fed. The other cultural practices were done as recommended. Foliar applications of boron were applied 80 days after planting by the rate of $200 \mathrm{~L} /$ fed. Some chemical and physical properties of the experimental soil before soil preparation was determined according to the procedures outlined by Jackson (1967) are shown in Table (1):

At harvest (195 days from sowing date), a random sample of twenty roots were sent to the laboratory, cleaned with running tap water, dried and grated with grater into cossettes, then mixed thoroughly to determine the quality characteristics according to Cooke and Scott (1993).

\section{Data recorded:}

A- Vegetative traits: Root length and diameter $(\mathrm{cm})$ were measured.

\section{B- Qualitative characteristics:}

1. Pol\% was estimated in fresh samples of sugar beet roots, using saccharometer according to the method described in AOAC, (2005).

2. Alpha amino nitrogen, sodium and potassium contents: were determined according to the procedure described by the sugar company using auto Analyzer AOAC, (2005). The results were calculated as milliequivalent per 100 gm beet.

3. Sugar recovery $\%$ was calculated according to Cooke and Scott (1993) using the following equation:

Sugar recovery $\%=$ Pol\% $-[0.29+0.343(\mathrm{~K}+\mathrm{Na})+\alpha \mathrm{N}$ (0.094)],

Table1. Some physical and chemical characteristics of the experimental soils*

\begin{tabular}{|c|c|c|}
\hline Properties & 2008/2009 Season & 2009/2010 Season \\
\hline \multicolumn{3}{|l|}{ Texture analysis: } \\
\hline Clay \% & 44.10 & 47.40 \\
\hline Silt \% & 31.50 & 28.60 \\
\hline Sand \% & 24.40 & 24.00 \\
\hline Texture grade: & Clay & Clay \\
\hline $\mathrm{pH}(1: 2.5$ suspention $)$ & 7.50 & 7.50 \\
\hline Ec m.mohs (1:1) & 1.32 & 1.15 \\
\hline Organic matter $\%$ & 1.17 & 1.24 \\
\hline \multicolumn{3}{|l|}{ Soluble cations: } \\
\hline $\mathrm{Ca}^{++}+\mathrm{Mg}^{++} \mathrm{meq} / 100 \mathrm{~g}$ soil & 0.96 & 0.84 \\
\hline $\mathrm{Na}^{+} \quad \mathrm{meq} / 100 \mathrm{~g}$ soil & 0.37 & 0.44 \\
\hline $\mathrm{K}^{+} \quad \mathrm{meq} / 100 \mathrm{~g}$ soil & 0.09 & 0.11 \\
\hline \multicolumn{3}{|l|}{ Soluble anions: } \\
\hline $\mathrm{CO}_{3}+\mathrm{HCO}_{3}$ meq/100g soil & 0.33 & 0.36 \\
\hline meq/100g soil & 0.84 & 0.91 \\
\hline Total N,\% & 0.09 & 0.10 \\
\hline Available P (ppm) & 17.8 & 18.4 \\
\hline B (ppm) & 0.36 & 0.38 \\
\hline Exchangeable K (meq/100g soil) & 0.64 & 0.71 \\
\hline
\end{tabular}

Where, $\mathrm{K}, \mathrm{Na}$ and $\alpha-\mathrm{N}$ were determined as milliequivalent $/ 100 \mathrm{~g}$ beet.

\section{C- Productivity parameters:}

1. Roots yield (ton /fed): At 195 days from sowing, plants of sugar beet from each plot were harvested to determine roots yield as ton /fed.

2. Recoverable sugar yield (ton/fed.) was calculated from the following equation: Recoverable sugar yield $($ ton/fed. $)=$ Roots yield (ton/fed.) X Sugar recovery \%.as reported by Cooke and Scott (1993).

Data collected were subjected to the proper analysis of variance (ANOVA). The proper statistical analysis of all data was carried out according to lined by Gomez \& Gomez (1984). Homogeneity of variance using Hartly test and differences among treatments were evaluated by the least significant difference test (LSD) at 5\%.

\section{RESULTS AND DISCUSSIONS}

\section{I- Vegetative traits:}

Data in Tables (2 and 3) revealed that nitrogen fertilizer level had a significant effect on root length and diameter $(\mathrm{cm})$ of sugar beet in the two growing seasons and the combined .It could be noted from combined analysis that adding nitrogen fertilizer at 100 or $120 \mathrm{~kg} /$ fed caused an increase in root length of sugar beet by 8.58 and $11.32 \%$ and root diameter of sugar beet by 7.78 and $11.84 \%$ compared with the control (adding nitrogen fertilizer at $80 \mathrm{~kg} / \mathrm{fed}$,) 
Table 2. Effect of boron on root length $(\mathrm{cm})$ of sugar beet at different levels of nitrogen fertilizer

\begin{tabular}{|c|c|c|c|c|c|c|c|c|c|c|c|c|}
\hline \multirow{3}{*}{$\begin{array}{l}\text { Nitrogen } \\
\text { fertilizer } \\
\text { levels (A) }\end{array}$} & \multicolumn{4}{|c|}{ 2008/2009 season } & \multicolumn{4}{|c|}{$2009 / 2010$ season } & \multicolumn{4}{|c|}{ Combined } \\
\hline & \multicolumn{12}{|c|}{ Boron concentration $(\mathrm{g} / \mathrm{L})(\mathrm{B})$} \\
\hline & 0.0 & 0.5 & 1.0 & Mean & 0.0 & 0.5 & 1.0 & Mean & 0.0 & 0.5 & 1.0 & Mean \\
\hline $80 \mathrm{~kg} / \mathrm{fed}$ & 35.33 & 35.60 & 35.60 & 35.51 & 37.27 & 37.53 & 37.60 & 37.47 & 36.30 & 36.57 & 36.60 & 36.49 \\
\hline $100 \mathrm{~kg} / \mathrm{fed}$ & 38.50 & 38.77 & 38.80 & 38.69 & 40.50 & 40.60 & 40.53 & 40.54 & 39.50 & 39.68 & 39.67 & 39.62 \\
\hline $120 \mathrm{~kg} / \mathrm{fed}$ & 39.70 & 40.03 & 40.20 & 39.98 & 41.00 & 41.67 & 41.13 & 41.27 & 40.35 & 40.85 & 40.67 & 40.62 \\
\hline Mean & 37.84 & 38.13 & 38.20 & 38.06 & 39.59 & 39.93 & 39.76 & 39.76 & 38.72 & 39.03 & 38.98 & 38.91 \\
\hline F test & $* *$ & \multicolumn{2}{|c|}{ 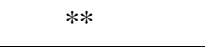 } & & $* *$ & $* *$ & \multicolumn{2}{|c|}{ Ns } & ** & $* *$ & \multicolumn{2}{|c|}{ Ns } \\
\hline LSD0.05 & \multicolumn{2}{|c|}{$\mathrm{A}=0.91 \quad \mathrm{~B}=$} & \multicolumn{2}{|c|}{$\mathrm{AB}=0.59$} & $A=0.16$ & $\mathrm{~B}=0.56$ & \multicolumn{2}{|c|}{$\mathrm{AB}=-$} & $A=0.39$ & $\mathrm{~B}=0.31$ & \multicolumn{2}{|c|}{$\mathrm{AB}=-$} \\
\hline
\end{tabular}

*, ** significant at 0.05 and 0.01 levels of probability, respectively.

Ns: Not significant.

Table 3. Effect of boron on root diameter $(\mathrm{cm})$ of sugar beet at different levels of nitrogen fertilizer

\begin{tabular}{|c|c|c|c|c|c|c|c|c|c|c|c|c|}
\hline \multirow{3}{*}{$\begin{array}{l}\text { Nitrogen } \\
\text { fertilizer } \\
\text { levels (A) }\end{array}$} & \multicolumn{4}{|c|}{ 2008/2009 season } & \multicolumn{4}{|c|}{$2009 / 2010$ season } & \multicolumn{4}{|c|}{ Combined } \\
\hline & \multicolumn{12}{|c|}{ Boron concentration $(\mathrm{g} / \mathrm{L})(\mathrm{B})$} \\
\hline & 0.0 & 0.5 & 1.0 & Mean & 0.0 & 0.5 & 1.0 & Mean & 0.0 & 0.5 & 1.0 & Mean \\
\hline $80 \mathrm{~kg} / \mathrm{fed}$ & 12.75 & 13.00 & 13.10 & 12.95 & 12.40 & 12.87 & 12.93 & 12.73 & 12.58 & 12.93 & 13.02 & 12.84 \\
\hline $100 \mathrm{~kg} / \mathrm{fed}$ & 13.73 & 14.00 & 14.10 & 13.94 & 13.50 & 13.80 & 13.90 & 13.73 & 13.62 & 13.90 & 14.00 & 13.84 \\
\hline $120 \mathrm{~kg} / \mathrm{fed}$ & 14.30 & 14.50 & 14.60 & 14.47 & 14.07 & 14.30 & 14.40 & 14.26 & 14.18 & 14.40 & 14.50 & 14.36 \\
\hline Mean & 13.59 & 13.83 & 13.93 & 13.79 & 13.32 & 13.66 & 13.74 & 13.57 & 13.46 & 13.74 & 13.84 & 13.68 \\
\hline F test & $* *$ & $*$ & $\mathrm{Ns}$ & & $* *$ & $* *$ & $\mathrm{Ns}$ & & $* *$ & $* *$ & $\mathrm{Ns}$ & \\
\hline LSD0.05 & $\mathrm{A}=0.41$ & $\mathrm{~B}=0.22$ & $\mathrm{AB}=-$ & & $A=0.16$ & $\mathrm{~B}=0.16$ & $\mathrm{AB}=-$ & & $\mathrm{A}=0.18$ & $\mathrm{~B}=0.13$ & $\mathrm{AB}=-$ & \\
\hline
\end{tabular}

respectively. Sarhan (1998); El-Hawary (1999) and Attia et al. (2004) revealed that the increment of growth attributes gained by increasing nitrogen fertilizer level may be due to the role of nitrogen in developing root dimensions by increasing division or elongation of cells and also enhancing leaf initiation and increment chlorophyll concentration in leaves and photosynthesis process.This was associated with accumulation of carbohydrates translocated from leaves to develop roots ,consequently increasing root size The aforementioned findings are in agreement with those of NemeatAlla(2005), Gomaa et al. (2005) and Awad-Allah et al. (2007).

Concerning the effect of boron, the data in Tables ( 2 and 3) showed that there were significant differences in root length and diameter $(\mathrm{cm})$ of sugar beet among the studied boron levels in both seasons and combined. It could be concluded from combined analysis that increasing the boron concentration from zero to 0.05 and $0.10 \%$ led to increase in root length $(\mathrm{cm})$ of sugar beet by 0.80 and $0.67 \%$ and root diameter $(\mathrm{cm})$ of sugar beet by 2.08 and $2.82 \%$, respectively. The aforementioned findings are in the same trend with those reported by Hassanin \& Abu El-Dahab (1991) and Narayan et al. (1991).

\section{II-Qualitative characteristics:}

Data presented in Tables (4 to 9) revealed that nitrogen fertilizer level had a significant effect on pol\%, sodium content, potassium content, amino nitrogen $(\alpha-$ $\mathrm{N})$ content, sugar recovery $\%$ and quality index of sugar beet in the two growing seasons and the combined except alpha amino nitrogen $(\alpha-\mathrm{N})$ content was insignificant in the $2^{\text {nd }}$ season .It could be noted from combined analysis that adding nitrogen fertilizer at 100 or $120 \mathrm{~kg} /$ fed caused a decrease in pol\% by 5.74 and $16.89 \%$, sugar recovery $\%$ by 9.47 and $26.71 \%$ and quality index by 3.01 and $8.52 \%$, while, there was an increase in sodium content by 20.86 and $34.53 \%$, potassium content by 15.24 and $32.13 \%$ and alpha amino nitrogen $(\alpha-\mathrm{N})$ content of beet roots by 23.49 and $35.57 \%$ compared with the control, respectively. Therefore, excessive nitrogen reduced pol\% of beet roots by partitioning of more photosynthetic to tops than the roots of sugar beet plants and the increase in nitrogen non-sucrose substances such as proteins, amino acids and other substances of beet root and consequently decreasing quality index and sugar recovery\% of sugar beet. Such data confirmed the previous reports of ElHawary (1999); El-Shafai (2000); Badawi et al. (2004) Nemeat-Alla(2005); Gomaa et al. (2005) and AwadAllah et al. (2007) who indicated similar findings. 
Table 4. Effect of boron on pol \% of sugar beet at different levels of nitrogen fertilizer

\begin{tabular}{|c|c|c|c|c|c|c|c|c|c|c|c|c|}
\hline \multirow{3}{*}{$\begin{array}{l}\text { Nitrogen } \\
\text { fertilizer } \\
\text { levels (A) }\end{array}$} & \multicolumn{4}{|c|}{ 2008/2009 season } & \multicolumn{4}{|c|}{ 2009/2010 season } & \multicolumn{4}{|c|}{ Combined } \\
\hline & \multicolumn{12}{|c|}{ Boron concentration $(\mathrm{g} / \mathrm{L})(\mathrm{B})$} \\
\hline & 0.0 & 0.5 & 1.0 & Mean & 0.0 & 0.5 & 1.0 & Mean & 0.0 & 0.5 & 1.0 & Mean \\
\hline 80 kg/fed & 14.70 & 14.95 & 15.05 & 14.90 & 15.15 & 15.48 & 15.60 & 15.41 & 14.93 & 15.22 & 15.33 & 15.16 \\
\hline $100 \mathrm{~kg} / \mathrm{fed}$ & 13.82 & 14.26 & 14.40 & 14.16 & 14.12 & 14.50 & 14.65 & 14.42 & 13.97 & 14.38 & 53 & 14.29 \\
\hline $120 \mathrm{~kg} / \mathrm{fed}$ & 12.65 & 12.90 & 13.13 & 12.89 & 12.80 & 12 & 1 & 13.05 & 12.73 & 13.00 & 13.19 & 12.97 \\
\hline Mean & 13.72 & 14.04 & 14.19 & 13.99 & 14.02 & 14.36 & 14.50 & 14.30 & 13.87 & 14.20 & 14.35 & 14.14 \\
\hline F test & $* *$ & & & Ns & $* *$ & & & Ns & $* *$ & * & & Ns \\
\hline LSD0.05 & $\mathrm{A}=0.13$ & & & $\mathrm{AB}=-$ & $\mathrm{A}=0.10$ & & & $\mathrm{AB}=-$ & $\mathrm{A}=0.07$ & & & $\mathrm{AB}=-$ \\
\hline
\end{tabular}

Table 5. Effect of boron on sodium content* of sugar beet of sugar beet at different levels of nitrogen fertilizer

\begin{tabular}{|c|c|c|c|c|c|c|c|c|c|c|c|c|}
\hline \multirow{3}{*}{$\begin{array}{l}\text { Nitrogen } \\
\text { fertilizer } \\
\text { levels (A) }\end{array}$} & \multicolumn{4}{|c|}{$2008 / 2009$ season } & \multicolumn{4}{|c|}{$2009 / 2010$ season } & \multicolumn{4}{|c|}{ Combined } \\
\hline & \multicolumn{12}{|c|}{ Boron concentration $(\mathrm{g} / \mathrm{L})(\mathrm{B})$} \\
\hline & 0.0 & 0.5 & 1.0 & Mean & 0.0 & 0.5 & 1.0 & Mean & 0.0 & 0.5 & 1.0 & Mean \\
\hline $80 \mathrm{~kg} / \mathrm{fed}$ & 1.50 & 1.45 & 1.42 & 1.46 & 1.40 & 1.30 & 1.26 & 1.32 & 1.45 & 1.38 & 1.34 & 1.39 \\
\hline $100 \mathrm{~kg} / \mathrm{fed}$ & 1.85 & 1.75 & 1.70 & 1.77 & 1.65 & 1.60 & 1.51 & 1.59 & 1.75 & 1.68 & 1.61 & 1.68 \\
\hline $120 \mathrm{~kg} / \mathrm{fed}$ & 2.00 & 1.90 & 1.85 & 1.92 & 1.90 & 1.80 & 1.76 & 1.82 & 1.95 & 1.85 & 1.81 & 1.87 \\
\hline Mean & 1.78 & 1.70 & 1.66 & 1.71 & 1.65 & 1.57 & 1.51 & 1.58 & 1.72 & 1.63 & 1.58 & 1.65 \\
\hline F test & $* *$ & & ** & Ns & $* *$ & & & Ns & ** & & & Ns \\
\hline LSD0.05 & $A=0.03$ & & 0.09 & $A B=-$ & $\mathrm{A}=0.11$ & $B=$ & & $\mathrm{AB}=-$ & $A=0.05$ & & 05 & $\mathrm{AB}=-$ \\
\hline
\end{tabular}

Table 6. Effect of boron on potassium content*of sugar beet of sugar beet at different levels of nitrogen fertilizer

\begin{tabular}{|c|c|c|c|c|c|c|c|c|c|c|c|c|}
\hline \multirow{3}{*}{$\begin{array}{l}\text { Nitrogen } \\
\text { fertilizer } \\
\text { levels (A) }\end{array}$} & \multicolumn{4}{|c|}{ 2008/2009 season } & \multicolumn{4}{|c|}{ 2009/2010 season } & \multicolumn{4}{|c|}{ Combined } \\
\hline & \multicolumn{12}{|c|}{ Boron concentration $(\mathrm{g} / \mathrm{L})(\mathrm{B})$} \\
\hline & 0.0 & 0.5 & 1.0 & Mean & 0.0 & 0.5 & 1.0 & Mean & 0.0 & 0.5 & 1.0 & Mean \\
\hline $80 \mathrm{~kg} / \mathrm{fed}$ & 3.83 & 3.58 & 3.51 & 3.64 & 3.70 & 3.52 & 3.50 & 3.57 & 3.77 & 3.55 & 3.51 & 3.61 \\
\hline $100 \mathrm{~kg} / \mathrm{fed}$ & 4.51 & 4.34 & 4.26 & 4.37 & 4.15 & 3.90 & 3.82 & 3.96 & 4.33 & 4.12 & 4.04 & 4.16 \\
\hline $120 \mathrm{~kg} / \mathrm{fed}$ & 5.11 & 4.73 & 4.69 & 4.84 & 4.80 & 4.70 & 4.60 & 4.70 & 4.96 & 4.72 & 4.65 & 4.77 \\
\hline Mean & 4.48 & 4.22 & 4.15 & 4.28 & 4.22 & 4.04 & 3.97 & 4.08 & 4.35 & 4.13 & 4.06 & 4.18 \\
\hline F test & \multicolumn{2}{|c|}{ ** } & ** & Ns & ** & & ** & Ns & \multicolumn{2}{|c|}{$* *$} & ** & Ns \\
\hline LSD0.05 & \multicolumn{2}{|c|}{$\mathrm{A}=0.24$} & $\mathrm{~B}=0.05$ & $\mathrm{AB}=-$ & $A=0.11$ & & $=0.09$ & $A B=-$ & $\mathrm{A}=0$ & & $\mathrm{~B}=0.05$ & $A B=-$ \\
\hline
\end{tabular}

*= Potassium content as milliequivalents / 100 gm beet

Table 7. Effect of boron on $\alpha$-amino nitrogen content*of sugar beet at different levels of nitrogen fertilizer.

\begin{tabular}{|c|c|c|c|c|c|c|c|c|c|c|c|c|}
\hline \multirow{3}{*}{$\begin{array}{l}\text { Nitrogen } \\
\text { fertilizer } \\
\text { levels (A) }\end{array}$} & \multicolumn{4}{|c|}{$2008 / 2009$ season } & \multicolumn{4}{|c|}{$2009 / 2010$ season } & \multicolumn{4}{|c|}{ Combined } \\
\hline & \multicolumn{12}{|c|}{ Boron concentration $(\mathrm{g} / \mathrm{L})(\mathrm{B})$} \\
\hline & 0.0 & 0.5 & 1.0 & Mean & 0.0 & 0.5 & 1.0 & Mean & 0.0 & 0.5 & 1.0 & Mean \\
\hline $80 \mathrm{~kg} / \mathrm{fed}$ & 1.66 & 1.50 & 1.42 & 1.53 & 1.57 & 1.42 & 1.35 & 1.45 & 1.62 & 1.46 & 1.39 & 1.49 \\
\hline $100 \mathrm{~kg} / \mathrm{fed}$ & 2.10 & 1.80 & 1.72 & 1.87 & 2.00 & 1.74 & 1.65 & 1.80 & 2.05 & 1.77 & 1.69 & 1.84 \\
\hline $120 \mathrm{~kg} / \mathrm{fed}$ & 2.30 & 2.10 & 1.88 & 2.09 & 2.15 & 1.87 & 1.79 & 1.94 & 2.23 & 1.99 & 1.84 & 2.02 \\
\hline Mean & 2.02 & 1.80 & 1.67 & 1.83 & 1.91 & 1.68 & 1.60 & 1.73 & 1.96 & 1.74 & 1.64 & 1.78 \\
\hline F test & \multicolumn{2}{|l|}{$* *$} & $* *$ & Ns & Ns & \multicolumn{2}{|c|}{$* *$} & Ns & $* *$ & \multicolumn{2}{|c|}{$* *$} & Ns \\
\hline LSD0.05 & $A=0.05$ & \multicolumn{2}{|c|}{$\mathrm{B}=0.09$} & $\mathrm{AB}=-$ & $A=-$ & \multicolumn{2}{|c|}{$\mathrm{B}=0.12$} & $\mathrm{AB}=-$ & $\mathrm{A}=0.02$ & \multicolumn{2}{|c|}{$\mathrm{B}=0.07$} & $\mathrm{AB}=-$ \\
\hline
\end{tabular}

\footnotetext{
$*=\alpha$-amino nitrogen content as milliequivalents $/ 100 \mathrm{gm}$ beet.
} 
Table 8. Effect of boron on sugar recovery\% of sugar beet at different levels of nitrogen fertilizer

\begin{tabular}{|c|c|c|c|c|c|c|c|c|c|c|c|c|}
\hline \multirow{3}{*}{$\begin{array}{l}\text { Nitrogen } \\
\text { fertilizer } \\
\text { levels (A) }\end{array}$} & \multicolumn{4}{|c|}{ 2008/2009 season } & \multicolumn{4}{|c|}{ 2009/2010 season } & \multicolumn{4}{|c|}{ Combined } \\
\hline & \multicolumn{12}{|c|}{ Boron concentration $(\mathrm{g} / \mathrm{L})(\mathrm{B})$} \\
\hline & 0.0 & 0.5 & 1.0 & Mean & 0.0 & 0.5 & 1.0 & Mean & 0.0 & 0.5 & 1.0 & Mean \\
\hline $80 \mathrm{~kg} / \mathrm{fed}$ & 12.44 & 12.82 & 12.94 & 12.73 & 12.54 & 13.41 & 13.54 & 13.17 & 12.49 & 13.12 & 13.24 & 12.95 \\
\hline $100 \mathrm{~kg} / \mathrm{fed}$ & 11.15 & 11.76 & 11.91 & 11.60 & 11.65 & 12.16 & 12.37 & 12.06 & 11.40 & 11.96 & 12.14 & 11.83 \\
\hline $120 \mathrm{~kg} / \mathrm{fed}$ & 9.71 & 10.14 & 10.42 & 10.09 & 10.01 & 10.40 & 10.61 & 10.34 & 9.86 & 10.27 & 10.52 & 10.22 \\
\hline Mean & 11.10 & 11.57 & 11.76 & 11.48 & 11.40 & 11.99 & 12.17 & 11.86 & 11.25 & 11.78 & 11.97 & 11.67 \\
\hline F test & $* *$ & * & & Ns & $* *$ & $*$ & & Ns & $* *$ & & & Ns \\
\hline LSD0.05 & $A=0.15$ & $\mathrm{~B}=\mathrm{C}$ & & $\mathrm{AB}=-$ & $\mathrm{A}=0.29$ & $\mathrm{~B}=0$ & & $\mathrm{AB}=-$ & $\mathrm{A}=0.14$ & $\mathrm{~B}=$ & & $\mathrm{AB}=-$ \\
\hline
\end{tabular}

Table 9. Effect of boron on quality index of sugar beet at different levels of nitrogen fertilizer

\begin{tabular}{|c|c|c|c|c|c|c|c|c|c|c|c|c|}
\hline \multirow{3}{*}{$\begin{array}{l}\text { Nitrogen } \\
\text { fertilizer } \\
\text { levels (A) }\end{array}$} & \multicolumn{4}{|c|}{ 2008/2009 season } & \multicolumn{4}{|c|}{ 2009/2010 season } & \multicolumn{4}{|c|}{ Combined } \\
\hline & \multicolumn{12}{|c|}{ Boron concentration $(\mathrm{g} / \mathrm{L})$ (B) } \\
\hline & 0.0 & 0.5 & 1.0 & Mean & 0.0 & 0.5 & 1.0 & Mean & 0.0 & 0.5 & 1.0 & Mean \\
\hline $80 \mathrm{~kg} / \mathrm{fed}$ & 84.62 & 85.78 & 85.98 & 85.46 & 82.81 & 86.63 & 86.81 & 85.42 & 83.72 & 86.20 & 86.40 & 85.44 \\
\hline $100 \mathrm{~kg} / \mathrm{fed}$ & 80.68 & 82.43 & 82.69 & 81.93 & 83.51 & 83.89 & 84.44 & 83.94 & 82.09 & 83.16 & 83.56 & 82.94 \\
\hline $120 \mathrm{~kg} / \mathrm{fed}$ & 76.73 & 78.60 & 79.34 & 78.23 & 78.23 & 79.39 & 80.08 & 79.23 & 77.48 & 79.00 & 79.71 & 78.73 \\
\hline Mean & 80.68 & 82.27 & 82.67 & 81.87 & 81.52 & 83.30 & 83.78 & 82.87 & 81.10 & 82.79 & 83.22 & 82.37 \\
\hline F test & $* *$ & & $*$ & Ns & $* *$ & & & Ns & $* *$ & & & Ns \\
\hline LSD0.05 & $\mathrm{A}=0.64$ & & 0.36 & $\mathrm{AB}=-$ & $\mathrm{A}=2.54$ & $\mathrm{~B}=$ & & $\mathrm{AB}=-$ & $\mathrm{A}=1.09$ & & & $\mathrm{AB}=-$ \\
\hline
\end{tabular}

Concerning the effect of boron, the recorded results in Tables (4 to 9) demonstrated that there were significant differences in pol\%, sodium content, potassium content, amino nitrogen $(\alpha-\mathrm{N})$ content , sugar recovery $\%$ and quality index of sugar beet among the studied boron levels in both seasons and combined .It could be concluded from combined analysis that increasing the boron concentration from zero to 0.05 and $0.10 \%$ led to increase in pol\% of sugar beet by 2.38 and $3.46 \%$, sugar recovery $\%$ of sugar beet by 4.71 and $6.40 \%$ and quality index of sugar beet by 2.08 and $2.61 \%$, while, there were decrease in sodium content of sugar beet by 5.52 and $8.86 \%$, potassium content of sugar beet by 5.32 and $7.14 \%$ and amino nitrogen $(\alpha-$ $\mathrm{N})$ content of sugar beet by 12.64 and $19.51 \%$, respectively.The aforementioned findings are in the same line with those reported by Nemeat- Alla \& ElGeddawy (2001).

\section{II- Yield parameters:}

Results in Tables 10 and 11 indicated that nitrogen fertilizer level had a significant effect on roots and recoverable sugar yields (ton/fed.) of sugar beet in the two growing seasons and the combined .It could be observed from combined analysis that the highest value of root yield (36.38 ton /fed) were recorded at level of $120 \mathrm{~kg} \mathrm{~N} / \mathrm{fed}$, but the highest value of recoverable sugar yield (4.18 tons/fed.) was recorded at level of $100 \mathrm{~kg}$ $\mathrm{N} /$ fed. The increase in root yield (ton/fed) caused by nitrogen application might be due to the favorable effect of nitrogen in building up the photosynthetic area of beet plants and consequently accumulation of more dry matter in root .Here too, the increase in recoverable sugar yields (ton/fed) of sugar beet with increasing nitrogen fertilizer level to $100 \mathrm{~kg} \mathrm{~N} / \mathrm{fed}$ might principally be attributed to the increase in root yield (ton/fed.) and small decrease in pol\% of beet roots compared with the other .Such data confirmed the previous reports of El-Shafai (2000);Badawi et al.(2004) Nemeat-Alla(2005); Gomaa et al. (2005) and Ferweez et al. (2006).

With regard to the effect of boron, the given results in Tables (10 and 11) showed that there were significant differences in roots and recoverable sugar yields (ton/fed.) of sugar beet as a result of foliar application with boron in both two seasons and combined. It could be concluded from combined analysis that increasing boron concentration from zero to 0.05 and $0.10 \%$ led to increase in root yield (ton/fed) of sugar beet by 3.55 and $4.78 \%$ and sugar yield (ton/fed) of sugar beet by 8.91 and $11.89 \%$, respectively. The aforementioned findings are in the same line with those reported by Nemeat-Alla \& El-Geddawy (2001).

Insignificant interactions were found between nitrogen fertilizer levels and boron concentrations (AB) with regard to all the studied traits of sugar beet in both seasons and combined (Tables 2to11).

Applying fertilization of sugar beet by $100 \mathrm{~kg} \mathrm{~N} / \mathrm{fed}$ with foliar application of boron with $0.10 \%$ (as boric acid) is recommended under Middle Egypt conditions (El-Minia Governorate conditions) because it gave the hightest value of recoverable sugar yield (4.39 ton/ fed) of sugar beet compared with the other levels of nitrogen and boron. 
Table 10. Effect of boron on root yield (ton/fed.) of sugar beet at different levels of nitrogen fertilizer

\begin{tabular}{|c|c|c|c|c|c|c|c|c|c|c|c|c|}
\hline \multirow{3}{*}{$\begin{array}{l}\text { Nitrogen } \\
\text { fertilizer } \\
\text { levels (A) }\end{array}$} & \multicolumn{4}{|c|}{ 2008/2009 season } & \multicolumn{4}{|c|}{$2009 / 2010$ season } & \multicolumn{4}{|c|}{ Combined } \\
\hline & \multicolumn{12}{|c|}{ Boron concentration $(\mathrm{g} / \mathrm{L})(\mathrm{B})$} \\
\hline & 0.0 & 0.5 & 1.0 & Mean & 0.0 & 0.5 & 1.0 & Mean & 0.0 & 0.5 & 1.0 & Mean \\
\hline $80 \mathrm{~kg} / \mathrm{fed}$ & 31.33 & 32.17 & 32.30 & 31.93 & 28.50 & 29.73 & 30.27 & 29.50 & 29.92 & 30.95 & 31.28 & 32.72 \\
\hline $100 \mathrm{~kg} / \mathrm{fed}$ & 34.80 & 36.20 & 36.90 & 35.97 & 33.20 & 35.10 & 35.50 & 34.60 & 34.00 & 35.65 & 36.20 & 35.28 \\
\hline $120 \mathrm{~kg} / \mathrm{fed}$ & 36.60 & 37.20 & 37.50 & 37.10 & 34.40 & 36.10 & 36.50 & 35.67 & 35.50 & 36.65 & 37.00 & 36.38 \\
\hline Mean & 34.24 & 35.19 & 35.57 & 35.00 & 32.03 & 33.64 & 34.09 & 33.26 & 33.24 & 34.42 & 34.83 & 34.13 \\
\hline F test & $* *$ & $* *$ & & Ns & $* *$ & $* *$ & & Ns & $* *$ & & $* *$ & $\mathrm{Ns}$ \\
\hline LSD0.05 & $\mathrm{A}=0.91$ & $\mathrm{~B}=0.34$ & $\mathrm{AB}$ & & $\mathrm{A}=0.16$ & $\mathrm{~B}=0.56$ & & & $\mathrm{~A}=0.39$ & & .31 & $\mathrm{AB}=-$ \\
\hline
\end{tabular}

Table 11. Effect of boron on sugar yield (ton/fed.) of sugar beet at different levels of nitrogen fertilizer

\begin{tabular}{|c|c|c|c|c|c|c|c|c|c|c|c|c|}
\hline \multirow{3}{*}{$\begin{array}{l}\text { Nitrogen } \\
\text { fertilizer } \\
\text { levels }(\mathrm{A})\end{array}$} & \multicolumn{4}{|c|}{$2008 / 2009$ season } & \multicolumn{4}{|c|}{$2009 / 2010$ season } & \multicolumn{4}{|c|}{ Combined } \\
\hline & \multicolumn{12}{|c|}{ Boron concentration (g/L) (B) } \\
\hline & 0.0 & 0.5 & 1.0 & Mean & 0.0 & 0.5 & 1.0 & Mean & 0.0 & 0.5 & 1.0 & Mean \\
\hline $80 \mathrm{~kg} / \mathrm{fed}$ & 3.89 & 4.13 & 4.18 & 4.07 & 3.57 & 3.99 & 4.10 & 3.89 & 3.73 & 4.06 & 4.14 & 3.98 \\
\hline $100 \mathrm{~kg} / \mathrm{fed}$ & 3.88 & 4.25 & 4.40 & 4.18 & 3.87 & 4.27 & 4.39 & 4.18 & 3.87 & 4.26 & 4.39 & 4.17 \\
\hline $120 \mathrm{~kg} / \mathrm{fed}$ & 3.55 & 3.77 & 3.91 & 3.75 & 3.45 & 3.75 & 3.87 & 3.69 & 3.50 & 3.76 & 3.89 & 3.72 \\
\hline Mean & 3.55 & 4.05 & 4.16 & 4.00 & 3.63 & 3.63 & 4.12 & 3.92 & 3.70 & 4.03 & 4.14 & 3.96 \\
\hline F test & $* *$ & & & Ns & $* *$ & & & Ns & $* *$ & & & Ns \\
\hline LSD0.05 & $\mathrm{A}=0.11$ & & & $\mathrm{AB}=-$ & $\mathrm{A}=0.09$ & $B=($ & & $\mathrm{AB}=-$ & $A=0.06$ & & & $\mathrm{AB}=-$ \\
\hline
\end{tabular}

\section{REFERENCES}

AOAC, (2005): Association of Official Analytical Chemists. Official methods of analysis, $26^{\text {th }}$ Ed., AOAC International, Washington, D.C., USA.

Attia, A.N.; A.A. Kandil; M.S. Sultan; M.A. Badawi and S.E. Seadh (2004): : Effect of planting dates, biofertilization and NK combination levels on :II- Yield and quality of sugar beet. The $4^{\text {th }}$ Scientific Conference of Agricultural Sciences, Assuit, December, 2004.

Awad-Allah, M.A.; E.A.Abd.El-Lattief and M.S.H. Ahmed (2007): Influence of nitrogen and sulphur fertilizer levels on productivity and technological charateristics of sugar beet under Middle Egypt conditions. Assiut J.of Agric.Sci., 38(3):1-16

Badawi, M.A.; A.A. Kandil; M.S. Sultan; A.N. Attia and S.E. Seadh (2004): Effect of planting dates, biofertilization and NK combination levels on: II- Yield and quality of sugar beet. The $4^{\text {th }}$ Scientific Conference of Agricultural Sciences, Assuit, December, 2004.

CCSC (2011): Central Council for Sugar Crops. Annual Report, Ministry of Agriculture and Land Reclamation, Egypt. (In Arabic)

Cooke, D.A. and, R.K. Scott (1993): The Sugar Beet Crop. Scientific Practice. Published by Chapman \& Hall, London.

EL-Hawary, M. A. (1999): Influence of nitrogen, potassium and boron fertilizer levels on sugar beet under saline soil conditions. J. Agric. Sci. Mansoura Univ., 24(4):15731581 .

El-Shafai, A.M.A. (2000): Effect of nitrogen and potassium fertilization on yield and quality of sugar beet in Sohag. Egypt. J. Agric. Res., 78(2): 759-767.
Ferweez, H.; H.M.Abbas and B. M. Abou El-Magd, (2006): Determination of the losses in yield, quality of sugar beet roots resulted from exceeding nitrogen fertilization and processing delay. Minia J. of Agric. Res. \& Develop: 26(1): 27-44,

Hassanin, M.A. and A. Abu El-Dahab (1991): Effect of foliar fertilization with micronutrients on yield and quality of sugar beet (Beta vulgaris L.).Bulletin of Fac. Agric. Univ., Cairo, 42(3): 663-672.

Gomaa, A.M.; H.Ferweez and A.M. Abo El-Wafa (2005): Maximizing yield quality and profitability of sugar beet using nitrogen fertilizer at different sowing dates under middle Egypt conditions. Assuit J. Agric. Sci. 36 (3): 3956.

Gomez, K.A. and A.A. Gomez (1984): Statistical Procedures for Agricultural Research, Second Edition. John Willey and Sons, New York, pp.680.

Jakson, M. L. (1967): Soil Chemical Analysis. Prentice - Hall, Inc, Englewood Cliffs, NJ, USA.

Narayan , D.; A.S.Chandel and G.R.Singh (1991): Effect of boron fertilization on yield and quality of sugar beet (Beta vulgaris L.). Indian J. of Plant Physiol. 32 (2): 164-168.

Nemeat-Alla, E.A.E.(2005): Yield and quality of sugar beet as affected by different nitrogen and sulphur rates under clayey soils .J.Agric. Sci. Mansoura Univ., 30(12):72557264.

Nemeat-Alla, E.A.E and I.H.M. El-Geddawy (2001): Response of sugar beet to foliar spraying time with micronutrients under different levels of nitrogen and phosphorus fertilization. J.Agric. Res. Tanta Univ., 27(4):670-681.

Sarhan, H.M. (1998): Macro-elements Requirements of Sugar Beet .M.Sc.Thesis, Fac. Agric. Mansoura Univ. 


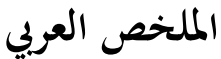

\section{تحسين ناتج وجودة بنجر السكر باستخدام البورن عند مستويات مختلفة من سماد النيتروجين}

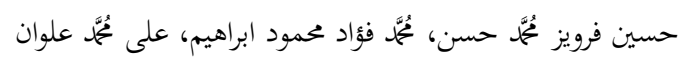

أوضحت النتائج المتحصل عليها الأني:

يعتبر الخفاض جودة بنجر السكر من المشاكل التي تواجه التوسع

1- أثرت كلا من مستويات السماد النيتروجينى و تركيزات البورن تأثيرا

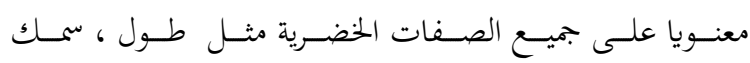

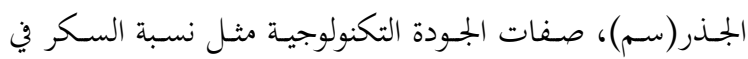

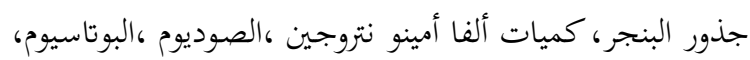

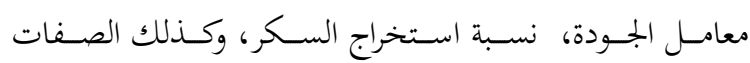

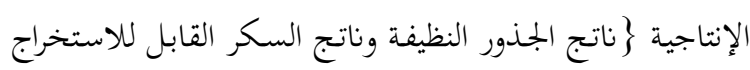

$$
\text { (طن/فدان) }
$$

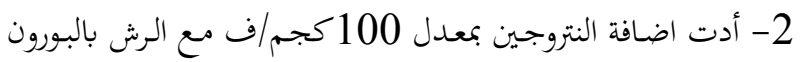

بتركيـز0.10\% الى تحقيق أعلى عحصـول للسـكر مـن الفــدان

$0($ (ن) 4.39$)$

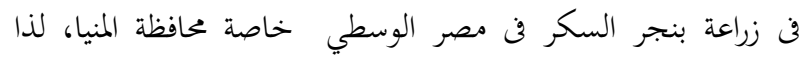
أقيمت بتربتان حقليتان بمحطة البحوث الزراعية بملوى، محافظة المنيا ،مصر خلال موسمى 2009/2008، 2010/2009 الإيجاد المعدل الامثل من البورن وسماد النتروجين الذي يعطى أعلى ناتج وجودة لجذور بنجر السكر في تصميم قطع منشقة مرة واحدة. وقد السداد

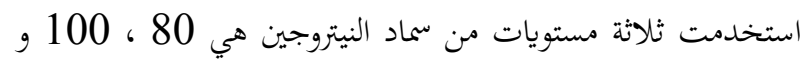
120 كجم/ف وزعت عشوائيا على القطع الرئيسية، وثلاثة تركيزات

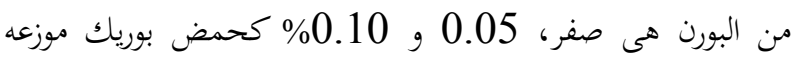

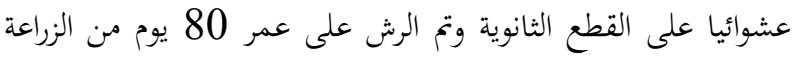
بمعدل 200 لتر / ف. 